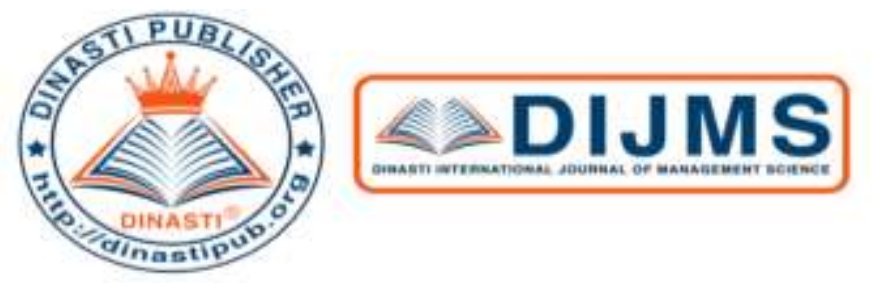

+62 81387654578

$+6281387654578$

https://dinastipub.org/DIJMS

dinasti-info@gmail.com

\title{
MODEL ANALYSIS OF PURCHASE DECISION
}

\section{Malikuddin Sembiring}

Universitas Tama Jagakarsa, Jakarta, Indonesia

\begin{tabular}{|c|c|}
\hline $\begin{array}{l}\text { ARTICLE INFORMATION } \\
\text { Received: 01 February } 2020 \\
\text { Revised: } 10 \text { February } 2020 \\
\text { Issued: } 20 \text { February } 2020 \\
\text { (filled in by Editor) } \\
\text { Corresponding author: first author } \\
\text { E-mail: } \\
\text { correspondent.author@ gmail.com }\end{array}$ & $\begin{array}{l}\text { Abstract: Low light brick purchasing decisions } \\
\text { constructs and real estate companies in Jakarta } \\
\text { Provincial allegedly caused by product, distribution, } \\
\text { promotion and customer value are still low. The purpose } \\
\text { of this research is to Determine and analyze the effect of } \\
\text { product, distribution, and promotion of partial or jointly } \\
\text { to customer value. To Determine and analyze the effect } \\
\text { of product, distribution, promotion and customer value } \\
\text { partially or jointly to the purchasing decision. The } \\
\text { population in this research amounted to } 964 \text { project } \\
\text { managers of } 241 \text { construction and real estate companies } \\
\text { in Jakarta. The method used in this research method was } \\
\text { a descriptive survey and explanatory survey with a } \\
\text { sample size of } 295 \text { respondents, and the data to the } \\
\text { analysis methods used are SEM (Structural Equation } \\
\text { Modeling) with } 8.70 \text { lisrel use application. Based on the } \\
\text { results of the research, the following research findings } \\
\text { product Obtained a positive and significant effect on } \\
\text { customer value. Distribution of significant effect on } \\
\text { customer value. Promotion significant effect on customer } \\
\text { value. Product, distribution, and promotion together } \\
\text { significant effect on customer value is equal to } 47 \% \\
\text { while the remaining 53\% is influenced by other factors. } \\
\text { Partially promotion of the most dominant effect on } \\
\text { customer value. The product does not affect the purchase } \\
\text { decision. Distribution of positive and significant effect } \\
\text { on purchasing decisions. Promotion of a positive and } \\
\text { significant impact on purchasing decisions. Customer } \\
\text { value of positive and significant effect on purchasing } \\
\text { decisions. Product, distribution, promotion and customer } \\
\text { value together positive and significant effect on } \\
\text { purchasing decisions is equal to } 81 \% \text { while the } \\
\text { remaining } 19 \% \text { are influenced by other factors. Partially } \\
\text { customers value the most dominant influence on } \\
\text { purchase decisions. } \\
\text { Keywords: Product, Distribution, Promotion, Customers } \\
\text { Value, Purchase Decision }\end{array}$ \\
\hline
\end{tabular}




\section{INTRODUCTION}

Police Jabar is Type B. Amount Sat Brimob personnel that ideally suits Jabar DSPP are 1714 people including 58 civil servants.

Redbrick is one of the building materials that become part of the foundation of building property. Lately, the material is a bit difficult to find Because the production process is very complicated and still a dependency with conventional heating the which is one of Global Warming factors, Because The combustion process cause of water pollution is certainly not environmentally friendly coupled with weather conditions and seasons of uncertainty that affect the price and availability of Reviews These materials (Kurniawan Wijaya, and Soemapraja, 2013: 1-5).

The use of conventional bricks will be replaced with the lightweight brick technology; sooner or later the use of red brick will switch to lightweight brick. This illustration can be used as benchmarks so fast construction technologies to make the switch. Lightweight brick is one of the products to support the program's "Green Peace". Greening for inhibiting "Global Warming" Because of the manufacturing process without the combustion process and the use of natural ingredients one of them is the seed Leak (Saparindus rarak) or commonly known as seed clerk. Refers to Reviews those conditions, through research, development, and innovation that create a lightweight brick the which is the nation's discovery of the children's work (Goritman, Irwangsa, and Kusuma, 2013: 4).

These lightweight bricks are solutions to problems in Indonesia, especially the development of the property industry. Because of light brick has many advantages. There are several advantages when used as a replacement brick light brick red (Goritman, Irwangsa, and Kusuma, 2013: 5), the which are: lightweight, robust, fast in; environmentally friendly; fireproof; earthquake-resistant; soundproof; can be directly in plain without plaster; bias installation using river sand or calcium mixed with cement mill. Another advantage of the light brick red brick and concrete block based on the "Unit Price Analysis Work With Work Unit Price Approach Field Theory and the" Department of Housing and Infrastructure Department of Public Works (2009) and "Building Material Specifications Part A (Nonmetallic Building Materials) "

With a wide target market, it could be Categorized into sections Several items, namely residential, high rise buildings, government projects and commercial projects with the customer target is the developer, contractor, and owner of the building itself. So with a very broad market, supported the need for lightweight bricks today and the future, the lightweight brick needs directly proportional to the needs of existing projects (Limanso, Witjaksono, Wumarlin, and Indra, 2010: 195). So concerning the broad target market, especially in Jakarta, then if it Refers to economic growth in the province of Jakarta, especially in the growth of construction and real estate Showed a positive trend.

The trend of growth in employment in the construction sector Showed an increase of every year, the highest growth occurred in 2012 roommates Reached 7:20\% Compared with the previous two years, reaching only $6: 20 \%$ in 2010 and 7:08\% in 2011, despite the drop growth in 2013 were only able to reach $6.85 \%$. Likewise, the growth in the real estate sector, where growth Showed an Increase until 2013 roommates Reached 5:35\% Compared with the 
previous three years that only $3.97 \%$ in $2010,4: 21 \%$ in 2011 and 5:31\% in 2012. (Source: Government Finance Report Province of Jakarta, 2013)

Increased growth in the construction sector employment and real estate sectors in Jakarta should be accompanied by the Increased rate of growth in sales of lightweight brick in the province of Jakarta, but in fact, the lightweight brisk sales growth rate fluctuated quite high. Lightweight brick sales growth rate in 2011 Decreased quite sharply, which only Reached 11:49\% Compared with the previous year's Reached roommates or Decrease Reached $27.71 \%-16.22 \%$. While in the same period of construction sector jobs Increased 7:08\% from the previous year roommates only Reached 6:20\% or an increase of $0.88 \%$, as well as terms of the real estate sector of the which rose 4:21\% previously Reached only Reached $3.98 \%$, or an Increase of 0:23\% growth. Then the drop in sales growth occurred in 2013 roommates only Reached 34.54\% Compared with the previous period to reach $45.32 \%$ or the Decrease of $-10.78 \%$, while the growth in jobs in the real estate sector in 2013 has roommates Increase Reached 5, 35\% compared with the previous year 2012 roommates Reached only 5:31\%. (Source: Sales of three Lightweight brick Company, the data processed, 2014)

It shows that both the construction sector and real estate sector in Jakarta is still Relatively low purchasing decisions in selecting the use of lightweight bricks in implementing and completing projects.

Many factors are thought to cause the still Relatively low purchasing decisions on the lightweight bricks made by the contractor, the construction and real estate in Jakarta. It is based on the results of the initial survey researcher (2014) against Several contractors (developers) construction and real estate in Jakarta, that (1) there is a tendency for developers to continue the project with red brick or block, meaning that there are still many developers or developers not to continue the project with a red brick or bataco, so the number of developers who continue the project with lightweight brick, its will be contested by the lightweight brick company. (2) The developers prefer red brick Generally the which is Considered to have proved its strength, (3) In general, the developers prefer red brick or bataco who has a strong image and good for the building, and (4) in general quite Often provide Recommendations to developers or other developers to use bricks that are currently used. (Source: Preliminary Survey Results, 2014)

Yee and Kay (2011: 264) states that "Decision-making process is the act that involves an analysis of the resulting in the selection of a course of action Among Several alternatives". That the decision-making process is an activity that involves analyzing results in choosing one course of action among several alternatives.

Purchasing decisions will be associated with the delivery of a message from the giver to the recipient of the message in question, with the purpose of the message recipient can make decisions by the wishes of the giver message. From a series of the communication process between the giver and the recipient, Kotler (2002: 274) Gave the following statement, "Ideally, the message should gain attention, hold interest, arouse desire and elicit action. In practice, few messages talk to the consumer from awareness through purchase, but the AIDA framework suggests the desirable qualities of any communication ". 
Based on the initial survey (2014) that has been Carried out on 30, project manager of developer or developer, found that $33 \%$ of the project manager enough attention to the role and function of brick for the completion of the project, so it is still very much the project manager who is not concerned with the extent of the role and function of a brick the chosen to support the quality of the project. A total of $28 \%$ of the project manager of the results of a survey of 30 project managers, it turns out they were not paying attention span required using bricks that have been chosen, and is therefore envisaged that there are many project managers who do not have a reference in the bricks of the type of brick as a building material on the project.

A total of $28 \%$ of project managers based on the results of the above survey, have enough interest in brick bricks offered by the company, however, the survey can not show the factors that make them interested in the brick chosen, especially the results of the survey showed no concern of the height of the project manager on the type of brick and timescales of brick used on the project was done. Furthermore, as many as $25 \%$ of the project manager stated they only need enough bricks to be used in the project of the brick company, in other words, they do not require real brick entirely had they use.

Lack of interest in and the lack of need for a project manager to brick bricks offered by the company, cause they do not seek information about the maximum information about the bricks that have been chosen, it is shown by the $30 \%$ of the project manager of the survey were not looking for information on the Whereabouts of brick. Referring to the survey that was conducted, it turns out $26 \%$ of the project manager wishes to use brick bricks offered by the company, can not be Described Although what underlies the project manager wants to select and use the bricks.

Based on the results of the survey (2014), it is not certain that the decision to choose products offered by the company will go through phases of AIDA (attention, interest, desire, action), as the project manager Showed Considerable interest but not fully paying attention, then the project manager shows but the choice is not based on a strong desire.

Many factors can lead to low purchasing decisions by developers choose when doing its lightweight brick projects. Gelb (2012: 1-8) Explains that cause consumers decide to buy a product is customer value itself the which is a comparison of the benefits/functionality with the cost of customers. Based on the above statement alleged that the developers lack the purchasing decision in choosing a lightweight brick in implementing Reviews their projects growing niche to be caused by lightweight brick Relatively customer value is still low. This is indicated resources by the results of the initial survey researcher (2014) the which has been Carried out on 30, project manager of developer or developer above, found that $33 \%$ of the project manager enough attention to the benefits of lightweight bricks for the customer, so it is still very much the project manager who does not care the extent to the which the role and function of the chosen brick can support the quality of the project. A total of $28 \%$ of the project manager of the results of a survey of 30 project managers, it turns out they were not paying attention span required using bricks that have been chosen and is therefore envisaged that the customer value of lightweight brick itself is Relatively low still perceived by the developers. 
Amusat, Adejumo, and Ajiboye (2013: 467) Explains that promotional tools can increase is extra customer value, so that the products offered are known to have a high value if the promotion is done right, and in line with product quality perceived by customers. Based on the above statement, the low-value customer lightweight brick was allegedly caused by a lack of proper promotion. This is indicated resources by the campaign Carried out by three manufacturers of lightweight bricks are just doing promotion as the promotion was conducted using face to face prospective customers, the promotion is done by making brochures and company profile, workshops, exhibitions and Several events of mass is usually done in Several events, and the promotion budget only Reached an average of $10 \%$ of total sales. While Weitz and Jap (1995: 305) explain that the creation of customer value can be enhanced through the distribution activity. Then Yamamoto (2002: 549) found that products that provide high benefits to customers can improve customer value itself. Based on Several expert opinions above, it can be said that the low value of lightweight brick customers growing niche to be the caused by lack of proper promotion activities, the distribution of the which is less precise, as well as the benefits of the product are not known in detail by the developers. It can be seen based on the initial survey (2014) roommates Showed that respondents Considered: (1) The quality of lightweight brick is still Relatively close to the bataco or other brick, but the cost is Initially greater, (2) A relatively equal distribution with other brick products,

So it is clear that the product is still Relatively lightweight brick unknown in detail by the user community, Including developers, Because customers are already accustomed to using brick or bataco product that has been shown to survive in the long impairment (Widjanarko, 2006: 14 ).

From all the above, the authors were interested and very important to research the analysis of lightweight brick purchasing decisions through customer value created by product, distribution, and promotion.

\section{LITERATURE REVIEW}

Product

The product is something that can be offered to the market to be considered, Possessed, used or consumed to satisfy the desire or need (Kotler and Armstrong, 2004: 337). While Tjiptono (2006: 95) states that it is the product conventional Subjective understanding of the manufacturer on something that could be offered as an attempt to achieve organizational goals through fulfilling the needs and desires of consumers, by the competence and capacity of the organization as well as purchasing power. Mc charity and Perreault (2003: 107) states that the product is a result of production that will be thrown to the consumer to be distributed and used consumers to meet Reviews their needs. The product is also a key element in the overall market supply (Kotler and Keller, 2008). Meanwhile, According to Saladin (2003: 121), the product is anything that can be offered to a market for attention, Possessed, used or consumed to satisfy the desires and needs. Based on the description concluded that the product is defined in this study as a result of the production to be marketed/sold to customers 
for distributed and utilized in meeting customer needs. The dimensions of the products in this study consisted of four dimensions, ie the dimensions of quality, features, design, and brand.

\section{Distribution}

Tjiptono (2008: 185) distribution can be defined as marketing activities that are trying to expedite and Facilitate the delivery of goods and services from producers to consumers, so its use as needed. Hollensen (2010: 14), the distribution is the way that it should be closer to customers. Usually thought of seeing marketing as a distribution channel that takes the product from the manufacturer to consumer. Kotler and Armstrong (2008: 60), is the distribution of tasks Involved in planning, implementing and controlling the flow of materials final goods, and related information from point of origin to point of consumption to meet customer needs in a condition to make a profit, Meanwhile, According to Solomon, Marshall, and Stuart (2008: 490) activities that are used to move goods from the manufacturer to the end customer, including order processing, warehousing, transportation, and inventory. From the description of the theory, it was concluded that the distribution is defined in this study is to move/switch items include planning, organizing, implementing, and monitoring the flow of goods /products from the manufacturer/dealer to the customer and to meet customer needs. The dimensions of distribution include four dimensions items, namely: the dimensions of order management, inventory, warehousing, and transportation dimensions.

\section{Promotion}

Saladin $(2003 ; 21)$, the campaign is a seller and a buyer of information communication that aims to change attitudes and behavior of the buyer, who was not familiar Become familiar with so that buying and keeping in mind the product. While Swastha (2003: 84) states that the promotion is the company's efforts to inform, persuade or remind consumers about companies, products, and ideas so that the goal can be achieved. In another sense, Private and Irawan (2008: 349) states that the promotion is the flow of information or persuasion in one direction are made to direct a person or organization to act that created the exchange in marketing. Like (2008: 133) states that the promotion is a communication from the seller and buyer are derived from precise information that aims to change attitudes and behavior of the buyer, who was not familiar Become familiar with so that it Becomes a buyer and still recall the product. Alma (2004: 181) states that promotion is a kind of communication that Explains to convince potential consumers of goods and services. Promotion mix a concoction of various promotional elements that are inside. According to Kotler (2009: 264), an element of the promotion mix (promotion mix) play device consists of five items, namely advertising, sales promotion, public relations, personal selling, and direct marketing. Based on the description of the theory, we conclude that the promotion is a way of communicating by the company to inform, persuade or remind consumers about companies, products, and ideas that aim to change attitudes and behavior of prospective buyers, who do not know Become familiar with so that it Becomes a buyer and still recall the product. The promotion consists of five dimensions, ie the dimensions of advertising, sales promotion, public relations, personal selling, and direct marketing dimension. 


\section{Customer value}

Alves (2010: 3), the value is the overall evaluation that the consumer makes of a product based on perceptions of that given in exchange for that which is received value delivery. Also, Alves added that Customer value is a customer's perceived preference for and evaluation of Reviews that product attributes attribute performances, and Consequences Arising from use that facilitate (or block), Achieving the customer's goals and purposes in usage situations.Sunarto (2006: 114), customer value is the difference between total customer value and total customer cost. Total customer value (total customer value) is a set of benefits that customers expect from a particular product or service. Total customer costs (total customer cost) is a set of expected costs incurred by the consumer to Evaluate, acquire, and dispose of the product or service. Kotler and Keller (2009: 259) states that the value of the customers is a combination of quality, service, price of a product offering. Ushered in customer value is the difference between the total value for the customer and the total cost of the customer, and the amount of value for the customer is a group of customers expected benefits of particular goods or services. While Wang et. al. (2004) dimensions of customer value divided into functional value, economic value, emotional value and the value of sacrifice. Based on the theoretical description it was concluded that the value of the customer is a consumer an overall assessment of the utility of a product based on perceptions of the received and given. The dimensions of customer value consist of four dimensions of functional value, social value, emotional value, and the value of sacrifice

\section{Purchase Decision}

Kotler and Keller (2012: 192), Stating the purchase decision is taken by the consumer decision process for purchasing products/services offered through the purchase decision process that includes consumers before making a purchase decision and at the time of purchase. The goal of any marketing of a product is satisfying the needs and desires of consumers or target customers. Therefore, consumers have significance in a company that is as a buyer of the product. According to Kotler (2012: 188) there are five decisions made by the buyer items, namely: (1) The selection of products and brands, consumers can make a decision to buy a product or use the money for other purposes; (2) Channel Selection, consumers must the make decisions about the which dealers will be visited. (3) Time Purchase, consumer decisions in the timing of purchase can vary; (4) Total purchases, consumers can the make decisions about how much of the product the which will be bought at any one time; (5) Payment method, consumers can take a decision on the payment method that will be used in the process of payment of the purchase, for example, transfer, cash, debit, and others. Based on the theoretical description above, it is concluded that the decision to purchase is defined as a process of consumer decision taken to purchase products offered through the purchase decision process that includes consumers before making a purchase decision and at the time of purchase. The dimensions of the purchase decision consist of five dimensions, ie the dimensions of the selection of products and brands, the selection of purchase channels, the time of purchase, amount/quantity of purchases, and the dimensions of payment. Consumers can the make decisions about how much of the product the which will 
be bought at any one time; (5) Payment method, consumers can decide on the payment method that will be used in the process of payment of the purchase, for example, transfer, cash, debit, and others. Based on the theoretical description above, it is concluded that the decision to purchase is defined as a process of consumer decision taken to purchase products offered through the purchase decision process that includes consumers before making a purchase decision and at the time of purchase. The dimensions of the purchase decision consist of five dimensions, ie the dimensions of the selection of products and brands, the selection of purchase channels, the time of purchase, amount/quantity of purchases, and the dimensions of payment. Consumers can the make decisions about how much of the product the which will be bought at any one time; (5) Payment method, consumers can decide on the payment method that will be used in the process of payment of the purchase, for example, transfer, cash, debit, and others. Based on the theoretical description above, it is concluded that the decision to purchase is defined as a process of consumer decision taken to purchase products offered through the purchase decision process that includes consumers before making a purchase decision and at the time of purchase. The dimensions of the purchase decision consist of five dimensions, ie the dimensions of the selection of products and brands, the selection of purchase channels, the time of purchase, amount/quantity of purchases, and the dimensions of payment.

\section{METHODOLOGY}

The object of research into the independent variable in this study is the product, distribution, and promotion. While the dependent variable is the value of customer and purchasing decisions. The nature of this research is descriptive and verification. Given the nature of this research is descriptive and verification conducted through the data collection in the field, the research method used is descriptive method survey and explanatory survey method. The unit of analysis in this study is a corporate customer in the construction and real estate company in Jakarta, the observation unit is the project manager. The time horizon in this study is cross-sectional, where research is done at one time simultaneously.

1. Product $(\xi 1)$ as independent variables

2. Distribution ( $\xi 2)$ as independent variables

3. Promotion ( $\xi 3)$ as independent variables

4. Customer value $(\eta 1)$ as an intermediate variable (intervening)

5. Purchase decisions ( $\eta 2)$ as the dependent variable.

In this study, as the object of analysis is the large construction company and real estate in the Jakarta with numbers is 241 companies, while the population (the unit of analysis) is the Project Manager of the construction company and a real estate size in Jakarta, as many as 964 project manager.

Taking into account the presence of the data outliers (Hair et al., 2006: 603) and the principle of the greater the sample size the better, then used a ratio of 1: 5, so with 59 parameters (indicators) of the Obtained sample size of at least:

$\mathrm{n}=$ number of parameters $\mathrm{x}$ variables

$=59 \times 5=295$ respondents 
To Determine the 295 selected samples was done by random sampling method is simple random sampling in 71 companies Construction and Real Estate in Jakarta.

\section{FINDINGS AND DISCUSSION}

Table 1. Hybrid (Full SEM) Suitability Model Size

\begin{tabular}{|l|l|l|l|}
\hline GOF INDICATORS & EXPECTED SIZE & $\begin{array}{c}\text { ESTIMATION } \\
\text { RESULTS }\end{array}$ & CONCLUSION \\
\hline Absolute Size Fit & GFI $>0.90$ & 0.98 & Good Fit \\
\hline GFI & RMSEA $<0.08$ & 0.72 & Good Fit \\
\hline RMSEA & NNFI $>0.90$ & 0.91 & Good Fit \\
\hline Incremental Size Fit & NFI $>0.90$ & 0.90 & Good Fit \\
\hline NNFI & AGFI $>0.90$ & 0.92 & Good Fit \\
\hline NFI & RFI $>0.90$ & 0.87 & marginal Fit \\
\hline AGFI & IFI $>0.90$ & 0.94 & Good Fit \\
\hline RFI & CFI $>0.90$ & 0.94 & Good Fit \\
\hline IFI & CFI
\end{tabular}

Source: Results of Treatment with LISREL 8.70

Based on Table 1 above, there are seven indices gained fitness models have a suitability index models (good fit) items, namely: RMSEA, GFI, NNFI, NFI, AGFI, IFI, and CFI. There are only one index suitability models that are undersize suitability good (RFI), but still, be within the scope of the suitability of the marginal (marginal fit). Marginal fit is the condition of the suitability of the measurement models under the criteria of absolute size fit, as well as incremental fit, but still can be passed on further analysis, Because it is close to the criteria of good size fit (Hair, et .all 2006: 623). Tus it can be continued on the next analysis.

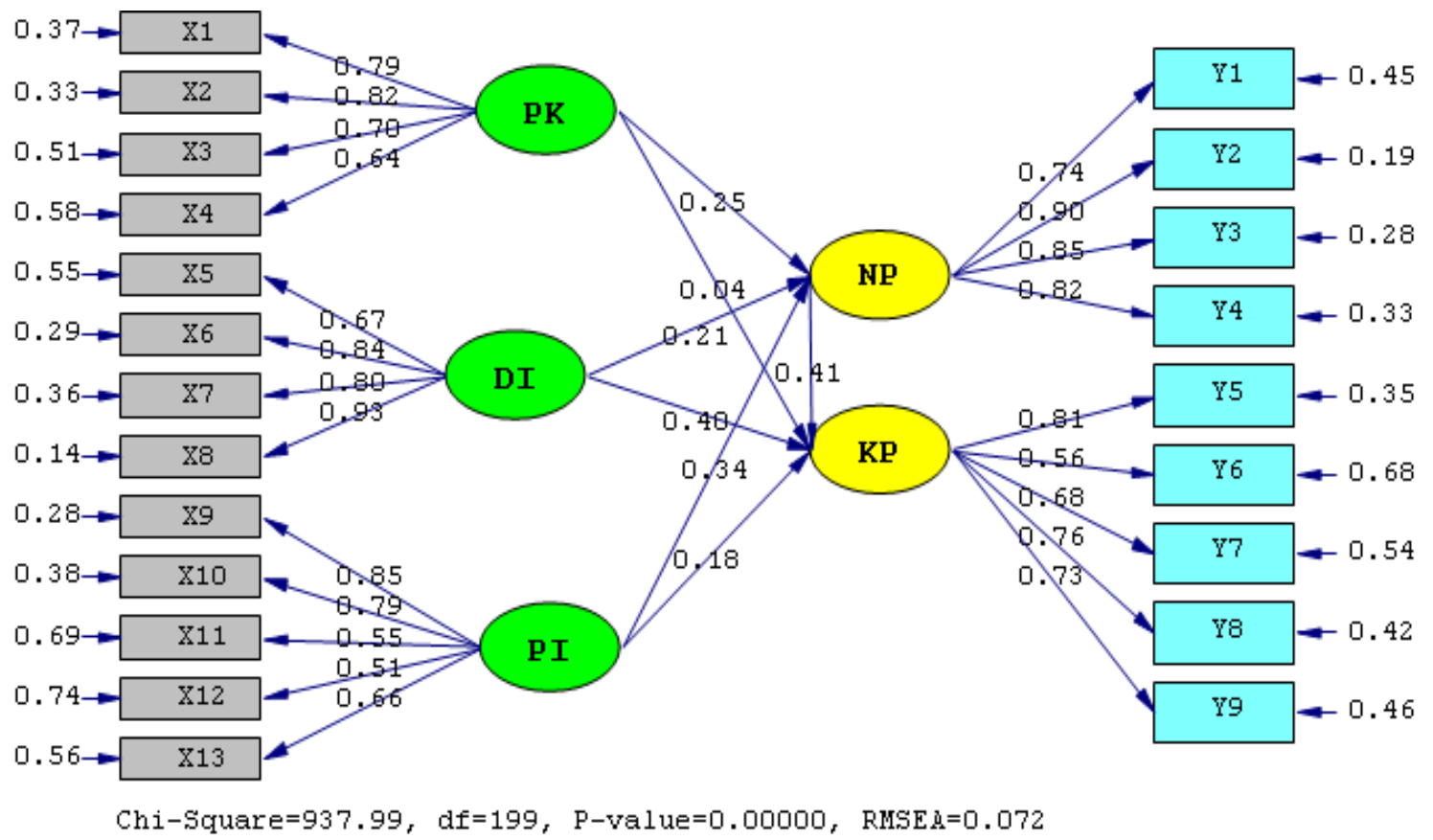

Figure 2. Hybrid (Full SEM) Standardized Model 


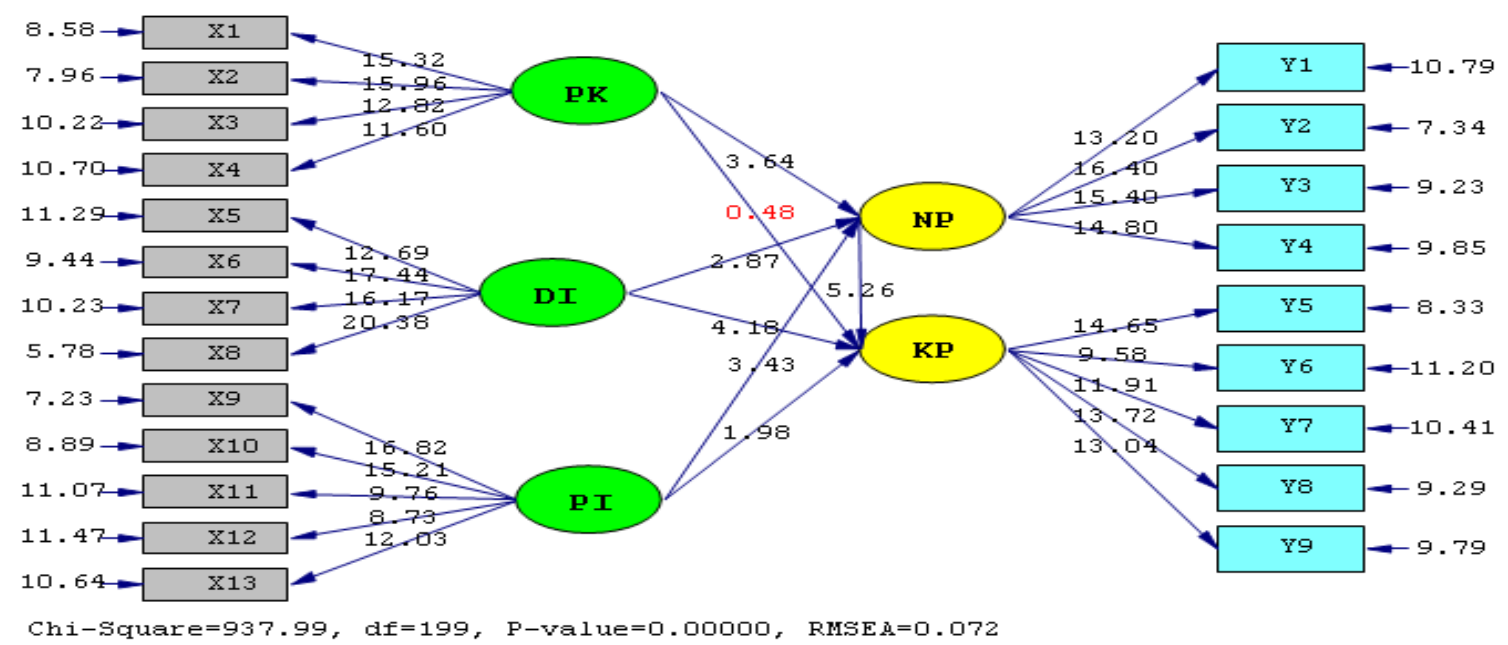

Figure 3. Hybrid (Full SEM) t-value model

Based on Figure 2 and Figure 3 above, the which is Followed by the analysis of hybrid measurement models (full model) of each variable, where all sub-variables in the formation of the latent exogenous variables product, distribution, promotion, and endogenous latent variable customer value and purchasing decisions have validity, well, this is indicated resources by all sub-variables have the Standardized Loading Factor (SLF) $\geq 0.5$ and $|\mathrm{t}| \geq 1,96$ value (at $\alpha=0.05$ ), (Hair, et. al., 2006 ).

\section{Table 2. Structural Equation Model}

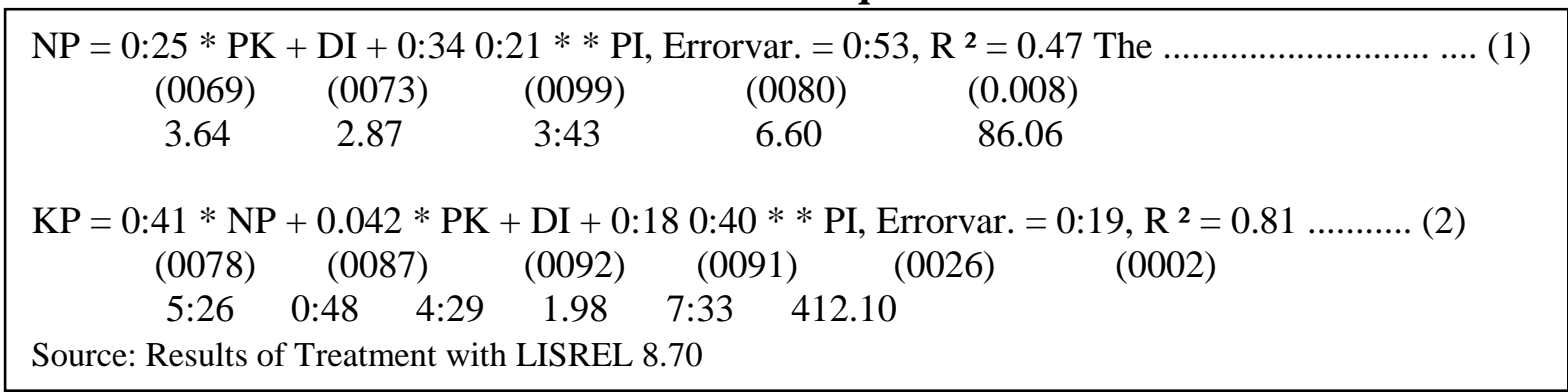

Table 3. Test of Variable Relationships

\begin{tabular}{|c|l|c|c|c|c|}
\hline No. & \multicolumn{1}{|c|}{ structural Tracks } & $\begin{array}{c}\text { SLF / } \\
\boldsymbol{R 2}\end{array}$ & $\begin{array}{c}\text { TValue } \\
\text { /Fvalue }\end{array}$ & $\begin{array}{c}\text { TTable } \\
\text { / Ftable }\end{array}$ & Test Results \\
\hline 1 & Product $\rightarrow$ Customer value & $0: 25$ & 3.64 & 1.96 & significant \\
\hline 2 & Distribution $\rightarrow$ Customer value & $0: 21$ & 2.87 & 1.96 & significant \\
\hline 3 & promotion $\rightarrow$ Customer value & $0: 34$ & $3: 43$ & 1.96 & significant \\
\hline 4 & $\begin{array}{l}\text { Products, Distribution and Promotion } \rightarrow \\
\text { Job satisfaction }\end{array}$ & $0: 47$ & 86.06 & 3.84 & significant \\
\hline 5 & Product $\rightarrow$ Buying decision & $0: 04$ & $0: 48$ & 1.96 & No Significant \\
\hline 6 & Distribution $\rightarrow$ Buying decision & $0: 40$ & $4: 18$ & 1.96 & significant \\
\hline 7 & promotion $\rightarrow$ Buying decision & $0: 18$ & 1.98 & 1.96 & significant \\
\hline 8 & Customer value $\rightarrow$ Buying decision & $0: 41$ & $5: 26$ & 1.96 & significant \\
\hline 9 & $\begin{array}{l}\text { Products, Distribution, Promotion and } \\
\text { Customer Value } \rightarrow \text { Employee loyalty }\end{array}$ & 0.81 & 412.10 & 3.84 & significant \\
\hline
\end{tabular}


Based on the results of hypothesis testing 1 to 4 in Table 3 above, the major direct and indirect effects of the products, distribution, and promotion of customer value are as follows:

Table 4.

Calculation results of the Direct and Indirect Effects of Production (PK), Distribution (DI) and Promotion (PI) for Customer Value (NP)

\begin{tabular}{|c|c|c|c|c|}
\hline \multirow{2}{*}{ variables } & \multicolumn{3}{|c|}{ Size of Influences } & \multirow[b]{2}{*}{ Total } \\
\hline & Direct & indirect & Remarks & \\
\hline \multirow{3}{*}{ Product $(\mathrm{PK})$} & 0.0625 & & & \multirow{3}{*}{.1421} \\
\hline & & .0320 & trough IN & \\
\hline & & .0476 & PI trough & \\
\hline \multirow{3}{*}{ Distribution (DI) } & .0441 & & & \multirow{3}{*}{.1225} \\
\hline & & .0320 & PK trough & \\
\hline & & .0464 & PI trough & \\
\hline \multirow{3}{*}{ Promotion (PI) } & .1156 & & & \\
\hline & & .0476 & PK trough & .2096 \\
\hline & & .0464 & trough IN & \\
\hline \multicolumn{3}{|c|}{ Influence of PK, DI, PI together against NP } & $R 2 K M B O K O$ & .4743 \\
\hline \multicolumn{3}{|c|}{ Beyond the influence of the variable NP } & $\zeta_{1}$ & .5257 \\
\hline
\end{tabular}

Source: Data Processing, 2014 (LISREL 8.70)

Whereas, the direct and indirect effects of the product, distribution, promotion, and customer value to the purchasing decision According to the results of hypothesis testing 1 to 4 in Table 3 above, are as follows:

Table 5.

Calculation results of the Direct and Indirect Effects of Production (PK), Distribution (DI), Promotion (PI) and Customer Value (NP) of the Purchase Decision (KP)

\begin{tabular}{|c|c|c|c|c|}
\hline \multirow{2}{*}{ variables } & \multicolumn{3}{|c|}{ large Influence } & \multirow[b]{2}{*}{ Total } \\
\hline & Directly & Indirect & Ket. & \\
\hline \multirow{4}{*}{ Products (PK) } & 0,0016 & & & \multirow{4}{*}{.0254} \\
\hline & & .0098 & trought IN & \\
\hline & & .0040 & thought PI & \\
\hline & & 0.0100 & thought NP & \\
\hline \multirow{4}{*}{ Distribution (DI) } & .1600 & & & \multirow{4}{*}{.3199} \\
\hline & & .0098 & thought PK & \\
\hline & & .0468 & thought PI & \\
\hline & & .1033 & thought NP & \\
\hline \multirow{4}{*}{ Promotion (PI) } & .0324 & & & \multirow{4}{*}{.1342} \\
\hline & & .0040 & thought PK & \\
\hline & & .0468 & trought IN & \\
\hline & & .0509 & thought NP & \\
\hline \multirow{4}{*}{$\begin{array}{c}\text { Customer Value } \\
\text { (NP) }\end{array}$} & .1681 & & & \multirow{4}{*}{.3323} \\
\hline & & 0.0100 & thought PK & \\
\hline & & .1033 & trought IN & \\
\hline & & .0509 & thought PI & \\
\hline \multicolumn{3}{|c|}{ Influence of PK, DI, PI, NP together against KP } & $\begin{array}{c}R 2 K M B O K O D \\
K\end{array}$ & .8118 \\
\hline \multicolumn{3}{|c|}{ Beyond the influence of the variable KP } & $\zeta_{2}$ & .1882 \\
\hline
\end{tabular}

Source: Data Processing, 2014 (LISREL 8.70) 
Based on the above models, Obtained some of the following:

1. TValueof the effect of the product against customer value amounted to 3.64>1.96, so it can be said to be significant, partially finished products Significantly Affect the value of the customer, the better the product means that produce company/manufacturer of lightweight brick, then the value of customers the construction and real estate companies will increase is, it is Tus Hypothesis 1 is accepted. Total contributions influence of Brick Light Product variable to variable customer value amounted to $14: 21 \%$.

2. TValueto influences the distribution of the partial customer value amounted to 2.86> 1.96, Thus Significantly influence the distribution of customer value, means the better distribution made by the company/manufacturer of lightweight brick good in aspects of management of orders, inventory, warehousing and aspects of transport, the customer value of construction and real estate companies will increase is, it is Tus Hypothesis 2 is accepted. The total contribution of the effect of the variable to variable Customer Value Distribution is $12: 25 \%$.

3. TValueto influence the promotion of customer value is part of $3: 43>1.96$, so that promotional significant effect on customer value, meaning that the higher sale of the company/manufacturer of lightweight bricks on the market, the customer value of construction and real estate companies will be Increased, it is Tus Hypothesis 3 is received. Total contributions influence the Promotions variable to variable customer value amounted to $20.96 \%$.

4. Fvaluevalue of the influence of product, distribution, and promotion of jointly towards customer value amounted to $86.06>3.84$, so it can be said to be significant, Thus the product, distribution, and promotion jointly positive and significant impact on customer value, it is Tus hypothesis 4 is received. The major contribution together variable products, distribution and promotion of customer value is $47 \%$, the remaining $53 \%$ is influenced by other factors. The most dominant factor is the factor of the partial campaign with a contribution of $20.96 \%$.

5. TValue of product influence on purchasing decisions is 0:48 $<1.96$, so it can be said to be significant, partially finished product does not influence on purchasing decisions, the which means that the better products that produce company/manufacturer of lightweight brick, then the purchase decision who performed construction and real estate companies is not necessarily Increased, it is Tus hypothesis is rejected 5. Total contributions influence of Brick Light Product variable to variable purchase decision amounted to $2: 54 \%$.

6. TValue for distribution influence on purchasing decisions are partially amounted to 4:18> 1.96, so that the distribution Significantly influence purchasing decisions, means the better distribution made by the company/manufacturer of lightweight brick good in aspects of management of orders, inventory, warehousing and aspects of transport, the purchasing decisions of construction and real estate companies will increase is, it is Tus accepted hypothesis 6 . The total contribution of the effect of the variable distribution of the variable purchase decision amounted to $31.99 \%$. 
7. TValue for promotion influence on purchase decisions are partially amounted to 1.98> 1.96 , so that the promotion of significant influence on purchasing decisions, meaning that the higher sale of the company/manufacturer of lightweight bricks on the market, the purchasing decision is made and construction company estate will increase is real, it is Tus accepted hypothesis 7 . Total contributions influence the Promotions variable to variable performance amounted to $13: 42 \%$.

8. TValueto influence customer value to the purchasing decision partially amounted to 5:26> 1.96, so that the customer value Significantly influence the purchasing decision, meaning that the higher the value of customers acquired construction and real estate companies in Jakarta, the purchase decision performed construction and real companies will increase is real, it is Tus hypothesis 8 accepted. Total contribution Customer Value variable influence on the purchase decision variable is equal to $33.23 \%$.

9. Fvalue of the influence of product, distribution, promotion, and customer value together on purchasing decisions amounted to $412.10>3.84$, so it can be said to be significant, Thus the product, distribution, promotion, and customer value together a positive effect and significant impact on the purchase decision, it is Tus hypothesis 9 is received. The major contribution together variable product, distribution, promotion, and customer value to the purchasing decision is at $81 \%$, the remaining $19 \%$ are influenced by other factors. The most dominant factor is the partial factor Customer Value with a contribution of $33.23 \%$

The above test results show that the direct variable Products, Distribution, and Promotion effect on the variable commitment Customer Value with a contribution of $47 \%$. Then the variable Products, Distribution, and Promotion directly Affect the purchase decision variable with a contribution of $31.52 \%$. But with Customer Value, Variable Products, Distribution and Promotion Increased influence the buying decision with a contribution of $81 \%$. So the results of this Study Also Showed that:

1. Customer value is Full mediating variables Affect the variable Product Purchase Decision

2. Customer value is the Partial Distribution and Promotion mediating variables that influence the buying decision.

The findings from this study is that the customer purchase decision on the users of lightweight brick construction and real estate company in Jakarta can be improved, especially in the selection of products and brand elements (Y5) if the Manufacturer / lightweight brick company can improve customer value, especially the elements of social value (Y2), where the Customer Value in lightweight brick users will be Able to be Increased if the manufacturer/company is Able to Increase the lightweight brick Promotions primarily elements Advertising (X9) and supported by the increasing lightweight brick products, especially in lightweight brick feature (X2) and supported Also by increasing the distribution of bricks especially light transport element (X8). 


\section{CONCLUSION AND SUGGESTION}

1. Lightweight brick products and significant positive effect on customer value, it means that the increase is in lightweight brick products will result in Increased customer value on the user's lightweight brick construction and real estate company in Jakarta. The most dominant element in shaping the lightweight brick products are lightweight brick feature elements especially in terms of the level of conformity with the features needed, compliance features to provide more value and features at a price level of conformity.

2. Distribution of lightweight brick and significant positive effect on customer value, meaning that an increase is in the distribution of lightweight brick doing will result in Increased customer value on the user's lightweight brick construction and real estate company in Jakarta. The most dominant element in shaping the distribution of lightweight brick is an element of transport, especially in terms of the availability of the fleet/transport adequate, speed of transport, and the level of product quality remains good.

3. Promotion of lightweight bricks positive and significant impact on customer value, it means that the increase is in the lightweight brick campaign will result in Increased customer value on the user's lightweight brick construction and real estate company in Jakarta. The most dominant element in shaping the lightweight brick campaign is advertising elements, especially in terms of the level of promotional media used the way of promotion and forms on display.

4. Products, Distribution and Promotion of lightweight bricks together positive and significant impact on customer value on the user's lightweight brick construction and real estate company in Jakarta with the coefficient of determination (R2) by 47\%, that 47\% Customer Value variable can be explained by jointly by the variable Products, Distribution, and Promotion while 53\% is influenced by other than Products, Distribution, and Promotion. Improvement Products, Distribution, and Promotion will result in Increased customer value, with the most dominant factor in increasing customer value is a Promotion of lightweight brick.

5. Lightweight brick products partially and not a significant positive effect on customer value, it means that the increase is in the lightweight brick product will not result in Increased customer purchasing decisions on the user's lightweight brick construction and real estate company in Jakarta.

6. Distribution of lightweight brick and significant positive effect on purchasing decisions, it means that the increase is in the distribution of lightweight brick doing will result in Increased purchasing decisions on the user's lightweight brick construction and real estate company in Jakarta. The most dominant element in shaping the distribution of lightweight brick is an element of transport, especially in terms of the availability of the fleet/transport adequate, speed of transport, and the level of product quality remains good.

7. Promotion of lightweight bricks positive and significant influence on purchasing decisions, it means that the increase is in the lightweight brick campaign will result in 
Increased purchasing decisions on the user's lightweight brick construction and real estate company in Jakarta. The most dominant element in shaping the lightweight brick campaign is advertising elements, especially in terms of the level of promotional media used the way of promotion and forms on display.

8. Lightweight brick's customer value has a significant positive effect on purchasing decisions; it means that the increase is in value will result in Increased customer purchasing decisions on the user's lightweight brick construction and real estate company in Jakarta. The most dominant element in the form of customer value lightweight brick is a social value, especially in terms of the level of social ties of the product and the confidence to use the product.

9. Products, Distribution, Promotion and Customer Value of lightweight brick have simultaneously positive and significant impact on the purchase decision in a lightweight brick users of construction and real estate company in Jakarta with the coefficient of determination (R2) by $81 \%$, that $81 \%$ of variable Purchase decision can be explained jointly by the variable Products, Distribution, and Promotion while 19\% is influenced by other than Products, Distribution, Promotion, and Customer Value. Improvement Products, Distribution, Promotion, and Customer Value will result in the user Increased buying decision at lightweight brick construction and real estate company in Jakarta, the most dominant factor in the buying decision is increasing customer value factors lightweight brick.

\section{REFERENCE}

Aila, Fredrick O., et al., All. 2012. Impact Of Channel Strategy On Customer Value Of Kenyan Soft Drink Companies. Interdisciplinary Journal of Contemporary Research in Business, VOL 3, NO 9

Alma, Buchari. 2004. Pemasarandan Management Service Marketing, Printing Sixth, Bandung, Alfabeta.

Alves, Helena. 2010. The Measurement of Perceived Value in Higher Education: a unidimensional approach. Universidade Da Beira Interior.

Amusat WA, Adejumo, and Ajiboye FA 2013. Sales Promotion As An antecedent Of Sales Volume: A Study Of Selected Manufacturing Industry In Ibadan, South-Western Nigeria. Interdisciplinary Journal of Contemporary Research in Business, VOL 4, NO 11

Arikunto, Suharsimi. 2002. Research Procedure A Practical Approach, Revised Ed VI, Jakarta, PT. Rineka Reserved.

Chi, Hsinkuang, Dr. Yeh, Huery Ren, Dr., and Tsai, Yi Ching. 2014. The Influences of Perceived Value on Consumer Purchase Intention: The Moderating Effect of Advertising Endorser, Journal of International Management Studies (JIMS), Vol 9 Number 1 ISSN 1993-1034

Chinomona, Richard., Okoumba, Loury., Pooe, David. 2013. The Impact of Product Quality on Perceived Value, Trust and Students' Intention to Purchase Electronic Gadgets. 
Mediterranean Journal of Social Sciences MCSER Publishing, Rome-Italy, Vol 4 No 14

Christina, Sagala, Destriani, Mila, daughter, Karina Ulffa, and Kumar, Suresh. 2014. Influence of Promotional Mix and Price on Customer Buying Decision sector toward Fast Food: A Survey on University Students in Jabodetabek (Jakarta, Bogor, Depok, Tangerang, Bekasi) Indonesia, International Journal of Scientific and Research Publications, Volume 4, Issue 1 ISSN 2250-3153

Denis Kurniawan, Tesar Julius Wijaya, and Tomy Gurtama Soemapraja. 2013. Analysis of Building Material Price Fluctuations In Jakarta

Public Works Department. 2009. Building Material Specifications Part A (Non-Metallic Building Materials). Public Works Department.

Department of Infrastructure Department of Public Works. 2009. Analysis Unit Price Unit Price Work Approach Work and Field Theory. public Works Department

Directory of Investment and Opportunity. 2013. Investment Opportunities Property Development. Director of Investment Services Engagement Office, Trade and Investment Asia Northern Territory Government, ISSN 2202-9958

Gelb. 2012. Customer Loyalty in the Oilfield: Familiarity. Houston, Texas. Gelb Consulting Group, Inc.

Gorman Birdyant, Irwangsa, Kusuma. 2013. Comparison of Different Brick Light of Segi Material, Cost and Productivity. Petra Christian University. Surabaya

Hair et. al .. 2006. Multivariate Data Analysis, Fifth Edition, Prentice-Hall, Upper Saddle River: New Jersy.

Hollensen, Svend. 2010. Marketing Management, Second edition. Harlow, Pearson Education Limited.

Jilly Bernadette Mandey. 2013. Promotion, Distribution, Price Influence on Purchase Decisions smoking. EMBA Journal Vol.1 No.4, Page. 95-104

Kotler, Philip, and Keller, Kevin L., Linguist Benjamin Molan. 2009. Marketing Management, Jakarta, PT.Indeks.

Kotler, Philip, and Keller. 2012. Marketing Management, Prentice Hall International, Inc. A Division of Simon \& Scuster, Englewood Cliffs, Nj07632.

Kotler, Philip, and Gary Armstrong. 2008. Principles of Marketing, Translation by Bob Sabran, Edition 8. Yogyakarta: PT. Index.

Kotler, Philip and Gary Armstrong. 2004. Basic-DasarPemasaran. Ninth Edition. Volume 2. Jakarta, PT.Indeks.

Kotler, Philip translated by Teguh Hendra, SE, Ak, Ronny A.Rusli, SE, Ak. And Drs. Benjamin Molan. Marketing Management 2002, Millennium Edition, Jakarta, PT.Indeks.

Like, Dawn. 2008. Marketing Management, and Practical Approach, Yogyakarta: Graha Science 
Limanso Sentosa, Witjaksono Yuda Endro, Wumarlin and Indra PW 2010. Productivity Lightweight Concrete Materials in usage as wall construction. 4th National Conference of Civil Engineering (context 4)

Mc. Carthy, Jerome, E. and William D. Perreault, Jr., in 2003. Basic-DasarPemasaran, EdisiKelima, AlihBahasa: Agus Dharma, Jakarta, Erland.

Murshid, Halim, M S., Osman, A. 2014. Marketing Mix Strategy and Physicians' Satisfaction: A Mediation Effect of Perceived Value in the Pharmaceutical industry in Yemen, IOSR Journal Of Humanities And Social Science (IOSR-JHSS), Volume 19, Issue 5, Ver. I, PP 73-81

Saladin, Djaslim. 2003. Marketing Management, Bandung, PT. Linda works.

Sugiyono. 2010. Qualitative and Quantitative Research Methods R \& D, Alfabeta Bandung.

Sunarto. 2006. 2. Marketing Management Yogyakarta: Adityamedia.

Swastha, Basu. 2003. Modern Marketing Management, second edition. Yogyakarta: Liberty.

Swastha, Basu, and Irawan. 2008. Modern Marketing Management, Molds Thirteenth. Yogyakarta, Liberty.

Taufik Rachim and Iwan Setiawan. 2014. The Effects of Product Attributes and Pricing Policy to Netbook Purchase Decision, International Journal of Science and Research (IJSR), ISSN: 2319-7064

Tjiptono, Fandy. 2008 Marketing Strategy, 3rd edition, Yogyakarta: Andi.

Tjiptono, Fandy. 2006. Management Services, Yogyakarta: Andi.

Wang, Yonggui, Po Hing Lo, Renyong Chi., And Yongheng Yang. 2004. An integrated framework for customer value and customer-relationship-management performance: a customer-based perspective from China, Managing Service Quality, Vol. 14, p. 169182

Weitz, Barton A and Sandy Jap. 1995. Relationship marketing and distribution channels. Journal of the Academy of Marketing Science, 23 (Fall), 305-320.

Widjanarko, Agoes. 2006. Technical Guidelines for Home and Building Earthquake Resistant Buildings equipped with Methods and How To Repair Damaged. Directorate General of Human Settlements - Department of Public Works.

Yamamoto Gonca Tellis. 2002. Understanding Customer Value Concept: Key To Success. Maltepe University, Faculty of Economics and Administrative Sciences, Business Department Deputy Head of the Department.

Yee, Audrey Sin Lye, and Keoy Kay Hooi. 2011. Consumer Decision-Making Behavior Critical Factors: An Exploratory Study. International Conference On Management (ICM 2011) Proceedings. 